\title{
STATISTICAL ANALYSIS OF THE FUNCTIONAL STATUS IN ORIENTEERS
}

\author{
V. I. Zalyapin ${ }^{1}$, zaliapinvi@susu.ru, \\ A. P. Isaev ${ }^{1}$, isaevap@susu.ru, \\ R. Y. Abzalilov ${ }^{2}$, abzalil.r@mail.ru, \\ E. V. Kharitonova ${ }^{1}$, kharitonova@susu.ru. \\ ${ }^{1}$ South Ural State University, Chelyabinsk, Russian Federation \\ ${ }^{2}$ Bashkir State Medical University, Ufa, Russian Federation
}

\begin{abstract}
The problem of physiological justification of effective adaptation and training technologies in orienteering is still under-investigated. However, as Russian and foreign literature gives a sufficiently detailed analysis of adaptive and compensatory processes of individual functional systems associated with training loads of various volume and purpose, we believe that mechanisms of short- and long-term adaptation in athletes should be studied from the perspective of integrative reactivity of the body. This research is dedicated to analysis of integrative reactivity, resistance, and tolerance in athletes. The problem of improvement of sport performance in orienteering (sprint and middle distances) during the training for socially important competitions was solved based on the assessment of status indicators and application of advanced techniques for the focused development of local-regional muscular endurance (LRME) at the plain and at the lower middle-altitude (800-1000m).

Keywords: intersystem and intrasystem relations, statistical analysis, analysis of variance, discriminant analysis.
\end{abstract}

\section{Introduction}

The primary aim of this research is to investigate the formation of effective adaptation in athletes during the training for major winter competitions. Working with adolescents it is important not only to develop special physical qualities and functional abilities as much as possible, but also to prepare athletes for the main competition in such a manner that will maintain their auxological characteristics within the reference limits without affecting their health $[1,2]$. Training in the basic period was based on gravitational and ballistic motor actions developing local-regional muscular endurance: cross-country running, step and jump imitation, jumping, hopping, jumping race, throwing, machine-based exercises, roller skiing, map training, and acrobatics combined with stretching, relaxation, swimming, massage, and sauna. The means for LRME development in the basic period took $60 \%$ of all training time. Applied methods included circuit training aimed to improve speedstrength qualities and strength endurance [1,3]. The first stage was devoted to overall physical conditioning (OPC), and during the second stage the number of specific physical conditioning (SPC) exercises was gradually increasing and eventually reached $40 \%$ of all training time. The basic training period was followed by the stage of conversion of physical qualities to motor skills; this stage lasted for a month minimum. LRME-developing exercise was gradually reduced to $30 \%$, and focus shifted to techniques forming specific endurance. For this purpose, along with conventional methods of sport training at the final stage (25-28 days), the competitive period was supplemented with interval training within the 
competitive fitness mesocycle [4]. The athletes had a series of races with intensity of 70$85 \%$ of maximum. Under these conditions, their heart rate varied within the range of 160-170 beats per minute (bpm) being 120-130 bpm in resting periods followed by another acceleration. Relative to the applied interval method, the distance was changing: 600, $500,400,300$, and $200 \mathrm{~m}$. Two weeks before competitions the distances were shortened by $100 \mathrm{~m}$, and one week before competitions - by 100m more. Using mixed techniques aimed to develop LRME helped in its transformation to specific endurance at the training stage immediately before the socially important competition. As a whole, it predetermined the formation of effective adaptation in its stable phase. Effect of such motor actions caused psychophysiological changes in the attention process, which was seen from indicators of accuracy and performance significantly growing thanks to specific motor actions (crosscountry running) $[5,6]$.

\section{The primary statistical analysis}

\subsection{Estimated indicators}

This study presents the results of observation over 13-14-year-old boys who had been going in for orienteering for 3-4 years and were qualified athletes (senior degrees II and III). In total, the study involved 17 young athletes. The main morphological indicators of the examined boys were as follows: body length $-173.60 \pm 2,56 \mathrm{~cm}$, , body weight $-56.50 \pm 1.72 \mathrm{~kg}$, body mass index $-18.90 \pm 0.28 \mathrm{~kg} / \mathrm{m} 2$. Body fat percentage was $15.80 \pm 0.46 \%$. The functional status indicators were assessed by the means of Schiller diagnostic equipment (Switzerland) [8]. The function of attention was estimated with the help of correction tasks, and the information processing rate was tested by the equipment of our own design. The level of physical fitness in the orienteers was evaluated by the tests developed by Voronov [9]. At the age of 13-14 orienteers are undergoing the stage of specialization, and it is essential to accurately assess their predisposition for sprint or middle distances. For that purpose, we studied the influence of several morphofunctional indicators on sport performance [11]. We estimated two groups of indicators: morphometric indicators including Pet-O2 - partial pressure of oxygen in expired air, EC - energy capacity, Pet-CO2 - partial pressure of carbon dioxide in expired air, BSR - body strain rate, AnT-HR - heart rate at anaerobic threshold, EO2 - ventilation equivalent for oxygen extraction ratio, ECO2 - ventilation equivalent for carbon dioxide extraction ratio, and resistance: for the torso (Sopr-tul), right (Sopr-n-r) and left (Soprn-l) legs, right (Sopr-r-r) and left (Sopr-r-l) arms, AnT VO2 - oxygen consumption per minute at anaerobic threshold, and AnT VCO2 - carbon dioxide volume at anaerobic threshold; and indicators of performance and fitness, such as $5000 \mathrm{~m}$ distance finish time in winter orienteering, standing long jump, shuttle run 4x9 м, cross-country running test, correction accuracy indicator (baseline), attention productivity indicator (baseline), aftercross accuracy indicator, and after-cross attention productivity indicator.

\subsection{Descriptive statistics and correlation}

The main characteristics of the first group are presented in Table 1 and of the second group - in Table 2. 
Table 1

Main Statistics of Morphofunctional Parameters

\begin{tabular}{|l|l|l|l|l|l|}
\hline & $\mathrm{N}$ & Minimum & Maximum & Mean & $\begin{array}{l}\text { Standard } \\
\text { deviation }\end{array}$ \\
\hline Pet-02 & 17 & 88.00 & 97.00 & 93.4118 & 2.89523 \\
\hline EC & 17 & 64.00 & 68.00 & 66.4118 & 1.22774 \\
\hline Pet-CO2 & 17 & 34.00 & 39.00 & 36.7059 & 1.53153 \\
\hline BSR & 17 & 100.00 & 106.00 & 102.8824 & 2.20461 \\
\hline AnT-HR & 17 & 160.00 & 166.00 & 163.6471 & 2.02920 \\
\hline EO2 & 17 & 23.00 & 29.00 & 26.0000 & 1.90394 \\
\hline ECO2 & 17 & 23.00 & 27.00 & 24.7647 & 1.39326 \\
\hline Sopr-tul & 17 & 568.00 & 588.00 & 575.4706 & 5.36327 \\
\hline Sopr-n-r & 17 & 244.00 & 256.00 & 250.0706 & 3.5672 \\
\hline Sopr-n-l & 17 & 244.00 & 256.00 & 248.5882 & 3.12368 \\
\hline Sopr-r-r & 17 & 310.00 & 320.00 & 316.2353 & 2.79574 \\
\hline Sopr-r-l & 17 & 392.00 & 402.00 & 397.0529 & 3.52071 \\
\hline AnT-VO2 & 17 & 3.69 & 3.74 & 3.7112 & 0,01576 \\
\hline AnT-VCO2 & 17 & 3.08 & 3.69 & 3.6324 & 0,14281 \\
\hline
\end{tabular}

Table 2

Main Statistics of Performance Indicators

\begin{tabular}{|l|l|l|l|l|l|}
\hline & $\mathrm{N}$ & Minimum & Maximum & Mean & $\begin{array}{l}\text { Standard } \\
\text { deviation }\end{array}$ \\
\hline $5000 \mathrm{~m}$ time & 17 & 1092.00 & 1150.00 & 1121.1765 & 15.52110 \\
\hline Long jump & 17 & 170.00 & 186.00 & 177.7647 & 4.81572 \\
\hline Shuttle run & 17 & 9.98 & 11.20 & 10.5447 & 0.47335 \\
\hline $\begin{array}{l}\text { Cross-country } \\
\text { running test }\end{array}$ & 17 & 3.20 & 3.73 & 3.5988 & 0.12237 \\
\hline Correction accuracy & 17 & 0.93 & 0.96 & 0.9459 & 0.01064 \\
\hline Productivity & 17 & 284.00 & 294.00 & 289.7059 & 3.61878 \\
\hline After-cross accuracy & 17 & 0.95 & 0.99 & 0.9700 & 0.01369 \\
\hline $\begin{array}{l}\text { After-cross } \\
\text { productivity }\end{array}$ & 17 & 294.00 & 347.00 & 309.8235 & 14.42756 \\
\hline
\end{tabular}

The degree of correlation between the indicators in these two groups was analyzed using the table of correlations and turned out to be insignificant for most indicators. For instance, in the first group the significant correlation was observed only for indicators presented in Table $3^{1}$.

Strong correlation was observed between Pet-O2 (partial pressure of oxygen in expired air) and ECO2 (ventilation equivalent of CO2), between partial pressure of $\mathrm{CO} 2$ in expired

\footnotetext{
${ }^{1}$ The first line in Tables 3 and 4 presents paired Pearson correlation, and the second line - significance. Significant correlations are bold-typed.
} 
Table 3

Significant Correlations between Indicators

\begin{tabular}{|l|l|l|l|l|l|}
\hline & Pet-O2 & EC & Pet-CO-2 & ECO-2 & AnT-VO-2 \\
\hline Pet-O2 & 1,000 & 0.2482 & 0.2264 & $\mathbf{- 0 . 7 0 2 7}$ & -0.3810 \\
\hline (level) & 0,000 & 0.3367 & 0.3823 & 0.0017 & 0.1313 \\
\hline EC & 0.2482 & 1,000 & $\mathbf{0 . 6 0 0 3}$ & $\mathbf{- 0 . 5 6 1 0}$ & -0.1558 \\
\hline (level) & 0.3367 & 0,000 & 0.0108 & 0.0191 & 0.5505 \\
\hline Pet-CO-2 & 0.2264 & $\mathbf{0 . 6 0 0 3}$ & 1,000 & -0.2102 & 0.0670 \\
\hline (level) & 0.3823 & 0.0108 & 0,000 & 0.4181 & 0.7983 \\
\hline ECO-2 & $\mathbf{- 0 . 7 0 2 7}$ & $\mathbf{- 0 . 5 6 1 0}$ & -0.2102 & 1,000 & $\mathbf{0 . 5 5 4 0}$ \\
\hline (level) & 0.0017 & 0.0191 & 0.4181 & 0,000 & 0.0210 \\
\hline AnT-VO-2 & -0.3810 & -0.1558 & 0.0670 & $\mathbf{0 . 5 5 4 0}$ & 1,000 \\
\hline (level) & 0.1313 & 0.5505 & 0.7983 & 0.0210 & 0,000 \\
\hline
\end{tabular}

air and energy capacity (EC), and also between the latter with ECO2. Medium correlation was observed between ECO2 and oxygen consumption at anaerobic threshold. Oxygen consumption is directly correlated with cardiac output and the arteriovenous oxygen difference $(A V D-O 2)_{2}$. Approximately $\frac{3}{4}$ of consumed oxygen is metabolized to carbon dioxide.

Table 4

Significant Correlations between Performance Indicators

\begin{tabular}{|l|l|l|l|l|}
\hline & $\begin{array}{l}\text { Shuttle } \\
\text { run }\end{array}$ & $\begin{array}{l}\text { Cross- } \\
\text { country } \\
\text { race }\end{array}$ & Productivity & $\begin{array}{l}\text { After-cross } \\
\text { productivity }\end{array}$ \\
\hline Shuttle run & 1,000 & $\mathbf{0 . 5 1 9 5}$ & $\mathbf{- 0 . 5 6 7 6}$ & $\mathbf{- 0 . 5 9 9 5}$ \\
\hline (level) & 0,000 & 0.0326 & 0.0175 & 0.0110 \\
\hline Cross-country race & $\mathbf{0 . 5 1 9 5}$ & 1,000 & -0.3904 & -0.4356 \\
\hline (level) & 0.0326 & 0,000 & 0.1213 & 0.0805 \\
\hline Productivity & $\mathbf{- 0 . 5 6 7 6}$ & -0.3904 & 1,000 & 0.4526 \\
\hline (level) & $\mathbf{0 . 0 1 7 5}$ & 0.1213 & 0,000 & 0.0681 \\
\hline After-cross productivity & $\mathbf{- 0 . 5 9 9 5}$ & -0.4356 & 0.4526 & 1,000 \\
\hline (level) & 0.0110 & 0.0805 & 0.0681 & 0,000 \\
\hline
\end{tabular}

The mechanism of correlations between $\mathrm{VO}_{2}$ and $\mathrm{VCO}_{2}$ may be, on the one hand, interpreted as a trigger stimulating the respiratory function, and on the other hand, as a mechanism mobilizing molecular-cellular processes at the level of skeletal muscles. The number of mitochondria grows, myosin is activated, and glycogen permeability rate increases. The anaerobic energy production and increases lactic acid production this acid starts interacting with bicarbonate buffer-source of extra $\mathrm{CO} 2$, which causes the increase of lung ventilation and VCO2 and disproportional growth of VO2 (lactate growth). Adequate ventilation index is linearly related to ventilation of physiological dead space and respiratory volume [10]. O2 uptake depends on the ability of the cardiovascular system to transport $\mathrm{O} 2$ to skeletal muscle. Here, the respiratory system has to supply $\mathrm{O} 2$ to the blood and to remove $\mathrm{CO} 2$, and under these conditions to provide aerobic synthesis of 
ATP. Respiratory threshold is developed due to metabolic acidosis (acidification of $\mathrm{pH}$ and increase of PCO2) observed when lactate threshold is reached [11]. The results of analysis of correlations between indicators obtained in tests (Table 4) (shuttle run, 3000m crosscountry race), attention productivity (correction tasks), and repeated studies after the cross-country race may be explained as follows: medium correlation between shuttle run and cross-country race results is associated with efficient influence of LRME on strength endurance. Inverse correlation with attention productivity is probably associated with the adolescents' increased excitability before shuttle run and their fatigue after the race $[6$, $12]$.

\section{Distance finish time}

For further discussion, it is important to note that the key indicator of athletes' performance - 5000m distance finish time in winter orienteering - did not significantly correlate with any indicator both from the first and the second groups. In order to understand the influence of chosen indicators on the performance on the distance we ranked distance finish times showed by the participants and clustered the participants based on the similarity of their results. Fig. 1 (left) shows the individual distance finish time for each of 17 participants, and Fig. 1 (right) - the same results in ascending order.
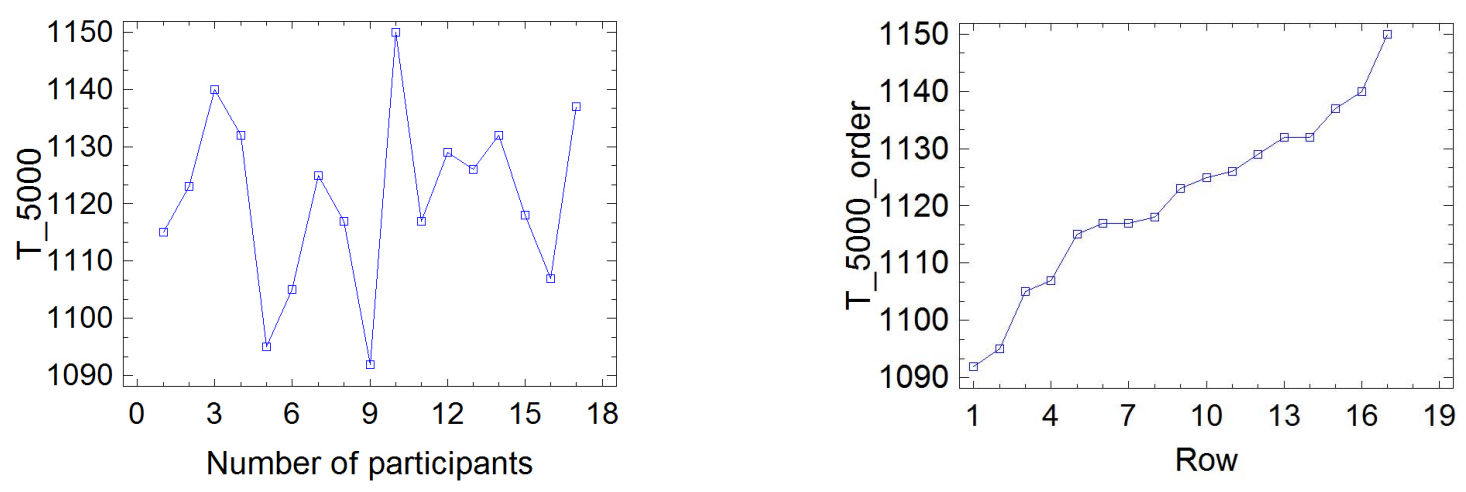

Fig. 1. Distance finishes time for each participant

Such classification allowed us to divide the examined sample into relatively homogenous groups based on the distance finish time (Table 5).

\section{Table 5}

Homogenous Groups

\begin{tabular}{|l|l|l|l|l|}
\hline Group & $\begin{array}{l}\text { Number } \\
\text { of } \\
\text { particip }\end{array}$ & Mean & Min & Max \\
\hline I & 4 & $1.1 \mathrm{E} 3$ & $1.09 \mathrm{E} 3$ & $1.11 \mathrm{E} 3$ \\
\hline $\mathrm{II}$ & 7 & $1.12 \mathrm{E} 3$ & $1.12 \mathrm{E} 3$ & $1.13 \mathrm{E} 3$ \\
\hline $\mathrm{III}$ & 5 & $1.13 \mathrm{E} 3$ & $1.13 \mathrm{E} 3$ & $1.14 \mathrm{E} 3$ \\
\hline IV & 1 & $1.15 \mathrm{E} 3$ & $1.15 \mathrm{E} 3$ & $1.15 \mathrm{E} 3$ \\
\hline Total & 17 & $1.12 \mathrm{E} 3$ & $1.09 \mathrm{E} 3$ & $1.15 \mathrm{E} 3$ \\
\hline
\end{tabular}


The conducted analysis of variance proved the reasonability of this classification, which may be seen from Fig. 2 and Table 6.

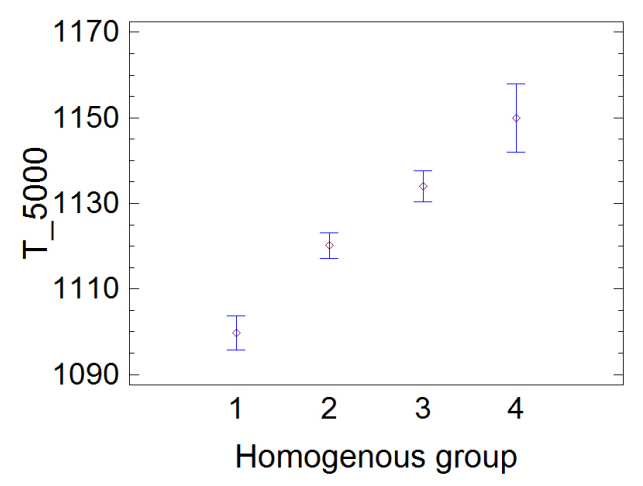

Fig. 2. Clustering based on distance finish times

Table 6

ANOVA of Distance Finish Times

\begin{tabular}{|l|l|l|l|l|}
\hline Source & $\begin{array}{l}\text { Sum of } \\
\text { squares }\end{array}$ & $\begin{array}{l}\text { Degrees } \\
\text { of } \\
\text { freedom }\end{array}$ & F-ratio & Signif \\
\hline Intergroup & $3.5 \mathrm{E} 3$ & 3 & 42.37 & 0.0000 \\
\hline Intragroup & 358. & 13 & & \\
\hline Total (Corr.) & $3.85 \mathrm{E} 3$ & 16 & & \\
\hline
\end{tabular}

Kruskal-Wallis nonparametric rank test also confirmed the validity of obtained clustering (Table 7) with the level of significance P-Value $=0.00247$.

Table 7

Kruskal-Wallis Test

\begin{tabular}{|l|l|l|}
\hline Group & $\begin{array}{l}\text { Number of } \\
\text { particip }\end{array}$ & $\begin{array}{l}\text { Mean } \\
\text { rank }\end{array}$ \\
\hline I & 4 & 2.5 \\
\hline II & 7 & 8.0 \\
\hline III & 5 & 14.0 \\
\hline IV & 1 & 17.0 \\
\hline
\end{tabular}

\section{Discriminant analysis}

Discriminant analysis of group of variables Pet-O2 (partial pressure of oxygen), EC (energy capacity), Pet-CO-2 (partial pressure of CO2), BSR (body strain rate), AnTHR (heart rate at anaerobic threshold), EO-2 (ventilation equivalent of oxygen), ECO-2 
(ventilation equivalent of CO2), Sopr-tul (torso resistance), Sopr-n-r (right leg resistance), Sopr-n=l (left leg resistance), Sopr-r-r (right arm resistance), Sopr-r-l (left arm resistance), and AnT -VO-2 (VO2 at anaerobic threshold) revealed that these variables accurately identified the homogenous group for each participant. The data of seventeen examined adolescents were used to calculate discriminant functions which made it possible to determine the homogenous group for each athlete. Standardized coefficients of discriminant functions are presented in Table 8.

\section{Table 8}

Coefficients of Discriminant Functions

\begin{tabular}{|l|l|l|l|}
\hline & $F_{1}$ & $F_{2}$ & $F_{3}$ \\
\hline Pet-O2 & -5.59 & 1.4 & 1.06 \\
\hline EC & 1.05 & 22.6 & 1.77 \\
\hline Pet-CO-2 & 10.2 & -15.5 & -1.89 \\
\hline BSR & 3.22 & 17.1 & 1.58 \\
\hline AnT-HR & -9.87 & -10.8 & 1.84 \\
\hline EO-2 & 7.48 & 7.32 & -0.302 \\
\hline ECO-2 & -12.8 & 8.52 & 0.866 \\
\hline Sopr-tul & -2.96 & 11.6 & -0.462 \\
\hline Sopr-n-r & -1.53 & -7.05 & 0.877 \\
\hline Sopr-n-I & -4.88 & 4.96 & -1.36 \\
\hline Sopr-r-r & -4.26 & -12.9 & -0.444 \\
\hline Sopr-r-I & -7.79 & 4.25 & 0.844 \\
AnT-VO-2 & 9.67 & -5.33 & 0.332 \\
\hline
\end{tabular}

Analyzing the ranking of discriminant function coefficients it should be noted that ventilation equivalent of $\mathrm{CO} 2$ and partial pressure of $\mathrm{CO} 2$ in expired air had the highest positions. Physiological mechanism of this process is the following. As aerobic production of energy by the cardiovascular system cannot provide sufficient energy for intensively working muscles, the anaerobic mechanism of bioenergetics is initiated $[2,6,10]$. Lactic acid is accumulated in blood and muscles, and its integration with bicarbonate buffer is the source of extra CO2; breathing is stimulated, so lung ventilation is increased [10, 11]. Activation of anaerobic metabolism at growing loads is accompanied by the increase in ventilation and VCO2 and by disproportional growth of VO2. This moment is called anaerobic threshold, which is proved by a high coefficient of heart rate at anaerobic threshold. The next important values are oxygen consumption at anaerobic threshold and ventilation equivalent of oxygen [12]. Along with gas exchange indicators, there is a similar ranking of resistance values depending on fat and muscle components of the composition of the body and limbs. The coefficient of resistance in arms seems to be the highest. Anaerobic threshold is recorded at the moment when O2 extraction is over $60 \%$ and when VO2 is over $60 \%$ of VO2max [10]. Anaerobic threshold reduces due to disturbed transport and utilization of $\mathrm{O} 2$ and insufficient recruiting of muscle fibers. In people with a low motor activity anaerobic threshold is observed at the load of 50-60 \% of VO2max, and in trained people - at a higher load. In many conditions, for instance, at heart deficiency, reaching anaerobic threshold means that the patient's efforts are sufficient and the test is informative. For instance, the first discriminant (standardized) function is the following:

$F_{1}=-5.59\left(\right.$ Pet $\left.-\mathrm{O}_{2}\right)+1.05 C E+10.2\left(\right.$ Pet $\left.-C_{2}\right)+3.22 B S R-9.87(A n T-H R)+7.48 E O_{2}$ 
$-12.8 \mathrm{ECO}_{2}-2.96($ Sopr - tul $)-1.53($ Sopr $-n-r)-4.88($ Sopr $-n-l)-4.26($ Sopr $-r-r)-$

$$
-7.79(\mathrm{Sopr}-r-r)+9.67\left(\mathrm{AnT}-\mathrm{VO}_{2}\right) \text {. }
$$

Classification is performed with the help of classifying functions coefficients of which are shown in Table 9.

Table 9

Coefficients of Classifying Functions

\begin{tabular}{|l|l|l|l|l|}
\hline & $C_{1}$ & $C_{2}$ & $C_{3}$ & $C_{4}$ \\
\hline Pet-O2 & $1.51 \mathrm{E} 3$ & $1.43 \mathrm{E} 3$ & $1.45 \mathrm{E} 3$ & $1.5 \mathrm{E} 3$ \\
\hline EC & $4.24 \mathrm{E} 3$ & $4.34 \mathrm{E} 3$ & $3.95 \mathrm{E} 3$ & $4.24 \mathrm{E} 3$ \\
\hline Pet-CO-2 & $-7.02 \mathrm{E} 3$ & $-6.76 \mathrm{E} 3$ & $-6.64 \mathrm{E} 3$ & $-6.98 \mathrm{E} 3$ \\
\hline BSR & $1.05 \mathrm{E} 3$ & $1.14 \mathrm{E} 3$ & 975. & $1.06 \mathrm{E} 3$ \\
\hline AnT-HR & $2.31 \mathrm{E} 3$ & $2.09 \mathrm{E} 3$ & $2.25 \mathrm{E} 3$ & $2.29 \mathrm{E} 3$ \\
\hline EO-2 & $-1.71 \mathrm{E} 3$ & $-1.52 \mathrm{E} 3$ & $-1.65 \mathrm{E} 3$ & $-1.69 \mathrm{E} 3$ \\
\hline ECO-2 & $7.36 \mathrm{E} 3$ & $6.97 \mathrm{E} 3$ & $6.95 \mathrm{E} 3$ & $7.31 \mathrm{E} 3$ \\
\hline Sopr-tul & 712. & 696. & 663. & 710. \\
\hline Sopr-n-r & 64.6 & 39.3 & 83.4 & 62.3 \\
\hline Sopr-n-I & 932. & 875. & 864. & 926. \\
\hline Sopr-r-r & -44.3 & -117. & -20.1 & -49.0 \\
\hline Sopr-r-I & $1.83 \mathrm{E} 3$ & $1.73 \mathrm{E} 3$ & $1.73 \mathrm{E} 3$ & $1.82 \mathrm{E} 3$ \\
\hline AnT-VO-2 & $-3.87 \mathrm{E} 5$ & $-3.63 \mathrm{E} 5$ & $-3.63 \mathrm{E} 5$ & $-3.84 \mathrm{E} 5$ \\
\hline CONSTANT & $-3.7 \mathrm{E} 5$ & $-3.46 \mathrm{E} 5$ & $-3.49 \mathrm{E} 5$ & $-3.66 \mathrm{E} 5$ \\
\hline
\end{tabular}

The first of the four classifying functions is calculated as follows:

$$
\begin{gathered}
C_{1}=-3.7 \cdot 10^{5}+1.51 \cdot 10^{3}(\text { Pet }-O 2)+4.24 \cdot 10^{3} E C-7.02 \cdot 10^{3}\left(\text { Pet }-C O_{2}\right)+ \\
1.05 \cdot 10^{3} B S R+2.31 \cdot 10^{3}(\text { AnT }-H R)-1.71 \cdot 10^{3} E_{2}+7.36 \cdot 10^{3} \mathrm{ECO}_{2}+ \\
+712 .(\text { Sopr }- \text { tul })+64.6(\text { Sopr }-n-r)+932 .(\operatorname{Sopr}-n-l)-44.3(\text { Sopr }-r-r)+ \\
+1.8310^{3}(\mathrm{Sopr}-r-l)-3.87 \cdot 10^{5}\left(\mathrm{AnT}-\mathrm{VO}_{2}\right) .
\end{gathered}
$$

The results of classification are given in Table 10 .

Table 10

Classification Table

\begin{tabular}{|l|l|l|l|l|l|}
\hline Group & $\begin{array}{l}\text { Number } \\
\text { of part. }\end{array}$ & \multicolumn{4}{|c|}{ Classification-determined group } \\
\hline & & $\mathrm{I}$ & $\mathrm{II}$ & $\mathrm{III}$ & $\mathrm{IV}$ \\
\hline $\mathrm{I}$ & 4 & 4 & 0 & 0 & 0 \\
\hline & & $(100.00 \%)$ & $(0.00 \%)$ & $(0.00 \%)$ & $(0.00 \%)$ \\
\hline II & 7 & 0 & 7 & 0 & 0 \\
\hline & & $(0.00 \%)$ & $(100.00 \%)$ & $(0.00 \%)$ & $(0.00 \%)$ \\
\hline III & 5 & 0 & 0 & 5 & 0 \\
\hline & & $(0.00 \%)$ & $(0.00 \%)$ & $(100.00 \%)$ & $(0.00 \%)$ \\
\hline IV & 1 & 0 & 0 & 0 & 1 \\
\hline & & $(0.00 \%)$ & $(0.00 \%)$ & $(0.00 \%)$ & $(100.00 \%)$ \\
\hline
\end{tabular}




\section{Conclusion}

1. All the sample under consideration may be with a high degree of significance divided into homogenous groups by distance finish time.

2. Discriminant analysis of group of variables Pet-O2 (partial pressure of oxygen), EC (energy capacity), Pet-CO-2 (partial pressure of carbon dioxide), BSR (body strain rate), AnT-HR (heart rate at anaerobic threshold), EO-2 (ventilation equivalent of oxygen), ECO-2 (ventilation equivalent of carbon dioxide), Sopr-tul (torso resistance), Sopr-n-r (right leg resistance), Sopr-n-l (left leg resistance), Sopr-r-r (right arm resistance), Soprr-l (left arm resistance), and AnT-VO-2 (VO2 at anaerobic threshold) reveals that that these variables accurately identify the homogenous group for each participant. Relative information value of indicators is presented in Table 8 .

3 . The research covers the physiological mechanism of prevalent influence of ventilation equivalent of $\mathrm{CO} 2$ and partial pressure of $\mathrm{CO} 2$ in expired air on the participant's affiliation to the certain group.

The work was supported by Act 211 Government of the Russian Federation, contract № 02.A03.21.0011

\section{References}

1. Voronov Y.S. Indicators of Speed-Strength Fitness and their Application in Multi-Year Training of Promising Young Orienteers. Sport, Olympism, Humanism: Collection of Scientific Papers. Smolensk, SGIFK Publ., 1999, pp. 45-49. (in Russian)

2. Voronov Y.S. Individualization of Training of Young Sportsmen, Going in for Sport Orienteering, on the Basis of the Age Appropriateness's account of Organism Biological Development. Uchenye zapiski universiteta imeni P.F. Lesgafta, 2008, no. 7(41), pp. 23-27. (in Russian)

3. Bliznevskaya V.S. Summer Training Of Skiers-Orienteers: Monograph. Krasnoyarsk, IPTs KGTU Publ., 2001. (in Russian)

4. Goryaeva E.Y. Physiological Mechanisms of Effects of Interval Hypobaric Endurance Training of Elite Orienteers. Proceedings of International Scientific Conference "Health-Promoting Technologies XXI". Chelyabinsk, Publishing Centre of SUSU, 2002, pp.131-138.(in Russian)

5. Zubkov S.A. Changes in Attention in Orienteering. Azimut, 1991, no. 12, pp. 26-28. (in Russian)

6. Suslov F.P., Cheshchikhina V.V. Laws of Integral Sport Working Capacity Manifested by Orienteers Relative to Intellectual and Physical Loads. Teoriya i practika fizicheskoy kultury, 1998, no. 8, p. 2. (in Russian)

7. Cheshchikhina V.V. Modern System of Training in Orienteering: Monograph. Moscow, Sovetsky Sport Publ., 2006. (in Russian)

8. Mamatov E.E., Isaev A.P., Nenasheva A.V., Mohsin A.S. Biomechanical Characteristics of the Spinal Column Scan, Functional and Metabolic Status in 
Elite Female Orienteers. Scientific and Methodological Support of the System of Physical Education and Sport Training in the Context of GTO (Ready for Labor and Defense) Complex Introduction: Proceedings of International Scientific Conference. Chelyabinsk, Publishing Centre of SUSU, 2015, pp. 71-77. (in Russian)

9. Voronov Y.S., Vasilyeva Z.V. Factors Determining Successful Performance in Orienteering and their Sense in Selection and Control of Athletes' Fitness. Young Scientists' Works. Smolensk, SGIFK Publ., 1997, pp. 14-16. (in Russian)

10. Raff H. Physiology Secrets, 2nd Edition. Hanley \& Belfus, 2002.

11. Smirnov V.N., Sandomirsky A.S. Orienteering: Monograph. Kiev, 2005. (in Russian)

12. Breslav I.S., Volkov N.I., Tambovtseva R.V. Breath and Muscular Activity of Athletes: Learning Guide in Physiology. Moscow, Sovetsky Sport Publ., 2013. (in Russian)

Vladimir I. Zalyapin, Candidate of Physico-Mathematical Sciences, Docent, Department of Mathematical Analysis and Methodology of Teaching Mathematics, South Ural State University (Chelyabinsk, Russian Federation), zaliapinvi@susu.ru

Alexander P. Isaev, Doctor of Biological Sciences, Professor, Department of Sports Technology and System Analysis, South Ural State University (Chelyabinsk, Russian Federation), isaevap@susu.ru

Rail Ya. Abzalilov, Departnent of the Physical Culture, Bashkir State Medical University (Ufa, Russian Federation), abzalil.r@mail.ru

Elena V. Kharitonova, Candidate of Physico-Mathematical Sciences, Docent, Department of Mathematical Analysis and Methodology of Teaching Mathematics, South Ural State University (Chelyabinsk, Russian Federation), kharitonovaev@susu.ru

Received January 10, 2017 


\title{
СТАТИСТИЧЕСКИЙ АНАЛИЗ ФУНКЦИОНАЛЬНОГО СОСТОЯНИЯ СПОРТСМЕНОВ-ОРИЕНТИРОВЩИКОВ
}

\author{
В. И. Заляпин, А. П. Исаев, Р. Я. Абзалилов, Е. В. Харитонова
}

\begin{abstract}
До настоящего времени проблема физиологического обоснования эффективной адаптации и технологии подготовки спортивного резерва представителей спортивного ориентирования остается недостаточно разработанной. Тем не менее, поскольку в отечественной и в зарубежной литературе достаточно полно дан анализ адаптивнокомпенсаторных процессов отдельных функциональных систем на тренировочные нагрузки разной мощности и направленности, механизмы срочной и долговременной адаптации спортсменов, на наш взгляд, должны исследоваться с позицией интегральной реактивности организма. Предметом настоящего исследования стал анализ интегративной реактивности, резистентности и толерантности организма спортсменов. Проблема повышения спортивной результативности представителей ориентирования (спринтерские и средние дистанции) при подготовке к социально-значимым стартам решалась нами на основе оценки индикаторов состояния и применения модернизированной технологии концентрированного развития локально-региональной мышечной выносливости (ЛРМВ) на равнине и в нижнем среднегорье (800-1000 м).

Ключевые слова: межсистемные, внутрисистемные связи, статистический (дисперсионный и дискриминантный) анализ.
\end{abstract}

\section{Литература}

1. Воронов Ю.С. Показатели скоростно-силовой подготовленности и их использование в многолетней тренировке перспективных юных ориентировщиков / Ю.С. Воронов // Спорт, олимпизм, гуманизм: сб. научн. трудов. - Смоленск: СГИФК, 1999. - C. 45-49.

2. Воронов Ю.С. Индивидуализация тренировки юных спортсменовориентировщиков на основе учета возрастных закономерностей биологического развития организма / Ю.С. Воронов // Ученые записки университета им. П.Ф. Лесгафта. - 2008. - № 7. - С. 23-27.

3. Близневская В.С. Тренировка лыжников-ориенторовщиков летом: монография / В.С. Близневская. - Красноярск: ИПЦ КГТУ, 2001.

4. Горяева Е.Ю. Физиологические механизмы действия интервальной гипобарической тренировки на выносливость спортсменов-ориентировщиков высокой квалификации / Е.Ю. Горяева // Материалы междунар. научно-практической конференции «Оздоровительные технологии ХХІ». - Челябинск: Изд-во ЮУрГУ, 2002.

5. Зубков С.А. Особенности динамики внимания в ориентировании на местности / С.А. Зубков // Азимут. - 1991. - № 12. - С. 26-28.

6. Суслов Ф.П. Закономерности проявления ориентировщиками интегральной спортивной работоспособности в связи с динамикой умственной и физической нагрузкой / Ф.П. Суслов, В.В. Чешихина // Теория и практика физической культуры. 1998. - № 8. - C. 2. 
7. Чешихина В.В. Современная система подготовки в спортивном ориентировании: монография / В.В.Чешихина. - М.: Советский спорт, 2006.

8. Маматов Э.Э. Биомеханичские характеристики сканирования позвоночника, функционального и метаболического состояния спортивных ориентировщиц высокой квалификации / Э.Э. Маматов, А.П. Исаев, А.В. Ненашева, Али Саджад Мохсин // Научно-методическое обеспечение и сопровождение системы физического воспитания и спортивной подготовки в контексте внедрения комплекса ГТО: материалы международной научной конференции (26-27 ноября 2015 г.); под общ. ред. В.В. Эрлиха, А.П. Исаева, А.И. Федорова. - Челябинск: Издат. центр ЮУрГУ, 2015. - С. 71-77.

9. Воронов Ю.С. Факторы, определяющие успешность соревновательной деятельности в ориентировании и их учет при отборе и контроле за уровнем подготовленности спортсменов / Ю.С. Воронов, З.В. Васильева / / Сб. научн. трудов молодых ученых. - Смоленск: СГИФК, 1997. - С.14-16.

10. Рафф Г. Секреты физиологии / Гершел Рафф; Пер. с англ. под общ. ред. Ю.В. Наточина. - М.: Бином; СПб.: Нев. диалект, 2001.

11. Смирнов В.Н. Ориентирование на местности: монография/ В.Н. Смирнов, А.С. Сандомирский. - Киев, 2005.

12. Бреслав И.С. Дыхание и мышечная активность человека в спорте: руководство для изучающих физиологию человека / И.С. Бреслав, Н.И. Волков, Р.В. Тамбовцева. - М.: Советский спорт, 2013.

Заляпин Владимир Ильич, кандидат физико-математических наук, доцент, кафедра математического анализа и методики преподавания математики, ЮжноУральский государственный университет (г. Челябинск, Российская Федерачия), zaliapinvi@susu.ru

Исаев Александр Петрович, доктор биологических наук, профессор, кафедра технологии спорта и системного анализа, Южно-Уральский государственный универcuтет (г. Челябинск, Российская Федерация), isaеvар@susu.ru

Абзалилов Раиль Ямилевич, кафедра физической культуры, Башкирский государственный медииинский университет (е. Уфа, Российская Федерачия), abzalil.r@mail.ru

Харитонова Елена Владимировна, кандидат физико-математических наук, доцент, кафедра математического анализа и методики преподавания математики, Южно-Уральский государственный университет (г. Челябинск, Российскал Федераu,u), kharitonovaev@susu.ru

Поступила в редакцию 10 января 2017 г. 